\title{
Introducing Beekeeping Within Microfinance Mechanisms to Combat Poverty Through the Agricultural Bank of Sudan (Case Study River Nile State)
}

\author{
Yasir Ahmed Abdalla Eltoum ${ }^{1}$, Yasein Hassan Ajeb Mohammed Nour ${ }^{2}$ \\ ${ }^{1}$ Department of Agricultural Economics, Faculty of Agriculture, Alzaiem Alazhari University, Khartoum North, Sudan \\ ${ }^{2}$ Agricultural Bank of Sudan, Khartoum, Sudan
}

Email address:

yasirtoum@yahoo.com·(Y.A.A. Eltoum), Yaseennoor85@gmail.com·(Y.H.A. M. Nour)

\section{To cite this article:}

Yasir Ahmed Abdalla Eltoum, Yasein Hassan Ajeb Mohammed Nour. Introducing Beekeeping Within Microfinance Mechanisms to Combat Poverty Through the Agricultural Bank of Sudan (Case Study River Nile State). International Journal of Agricultural Economics.

Vol. 5, No. 5, 2020, pp. 187-196. doi: 10.11648/j.ijae.20200505.16

Received: July 2, 2020; Accepted: July 20, 2020; Published: September 28, 2020

\begin{abstract}
This research deals with the subject of the introducing of beekeeping within microfinance mechanisms to combat poverty through the Agricultural Bank of Sudan. The research problem is the absence of beekeeping finance within the microfinance and poverty alleviation programs funded by the bank as a result of the lack of adequate information on the economic feasibility of the project in terms of profitability, the capital, payback period, the policy and qualified staff. To achieve the objectives of the research, the most important of which is introducing of beekeeping within the microfinance and poverty alleviation programs through the bank which covered different parts of Sudan and widespread in rural areas where poverty rate increases. The beekeeping in some areas of Sudan where forests covered large areas (rich flora) is considered the most successful projects, that lead to an increase in household income and thus reduce the poverty. Researcher relied on primary data collected from field survey as well as personal interviews with the Agricultural Bank of Sudan Micro-finance Initiative manager. Of the most prominent findings of the research that beekeeping in Sudan is most promising industry of high economic feasibility with an average production of colony per year of $19.3 \mathrm{Kg}$ and the rate of return on investment of $46.2 \%$, which confirms the feasibility of the project and its suitability for microfinance and poverty alleviation programs, the importance of the project is increasing in remote and rural areas and forests where it is difficult to construct any other projects, in addition to beekeeping lead to increased income to the farmers by increasing the productivity of the crops (River Nile State Initiative). The arguments in the research are intended to provide farmers and poverty reduction stakeholders in Sudan (including policy- makers) with the necessary information and motivation to consider beekeeping as viable commercial and protective activity that should always be considered and integrated in microfinance and poverty reduction programmes through the Agricultural Bank of Sudan. The researcher stated important recommendations. To encourage the banks and other financial institutes to engage in this type of investment, to create associations of local producers to develop productions and marketing process locally and abroad, to encourage the training and scientific research and to encourage beekeeping in order to be one of the agricultural inputs.
\end{abstract}

Keywords: Langstroth, Propolis, Bee Venom

\section{Historical Background}

The history of beekeeping in Sudan goes back to the $25^{\text {th }}$ Egyptian Dynasty, when Sudanese King Taharga (688-633 B. C) became the legitimate pharaoh of Egypt [14]. The bee was used as symbol to denote King Taharga. During the Christian age the plaster used in painting church was made of bee wax and other components all of which were mixed with honey.
Colonies of wild honey bees Apis mellifera ( $L$ ) are widely spread in central, western, southern and eastern states of the Sudan. They establish their nests in holes in trees and fallen logs, rocks, roofs and similar places. The natives search the forests for colonies of honey bees, guided by the bee eater bird (Merops spp) which rub their honey. Honey hunting, is an activity that is widely practiced in some forest areas in Kordufan, Darfur and Blue Nile where bees are abundant, but 
is a direct threat for the bees. The activity consists of plundering wild bee colonies. The honey hunter uses fire to chase the bees away and often kills the bee colony by burning it to facilitate the collection of honey. This is not only a direct threat for the bees but also for the forest as this type of fire is sometimes reported as the origin of forest fires and wild bush fires, destroying large parts of forests and habitats for bees and other pollinators. Some natives have been used local hives such as (Tangal) which made of dom leaves, canes, and barks hanging on the trees to attract swarm bees. The little bee (Apis florea) of the middle east were first recorded in Sudan in 1985 in Khartoum (Lordand Nagi, 1988) they build small single comb in shady treesand shrubs, but the honey is not easy to harvest without destroying the swarm and it is of low quantity. So it is of limited commercial significance with respect. In $1918 \mathrm{Mr}$. King made trials to improve the hive used by natives, he recommended the Khartoum hive made of dom leaves. But the swarm was not always attracted to enter them and became soft, fragile and rotten within one year. In 1932 Omdurman hive, made of mud was recommended by Mr. King as an alternative to the Khartoum hive. Since 1936, different types of hives have been used such as British standard hive. But it was expensive and need training for manufacturing them. The year 1961 consider the beginning of the introduction of the Langstroth standard hive for educational purposes in the University of Khartoum and today has been successful and extended to other parts of the country. Many projects have been made to improve and develop the beekeeping industry in Sudan such as the National Beekeeping Project in 1983, and the Sudanese Union for Beekeeping and Agriculture (SUBA) in 1988 as volunteer society aiming at developing traditional beekeeping in Sudan.

Types of Beekeeping in Sudan

Traditional beekeeping: as a type of land use activity offers a great potential for socio- economic development of residents and thus, plays regionally an important role in Sudan. Honey produced by traditional beekeeping constitutes more than $95 \%$ of beekeeping activity in Sudan and practiced in areas which use indigenous species and races of bees (Kurdofan, Darfur, Blue Nile). Traditional hives are made from whatever materials available locally: e.g. logs, bark, clay, grass, cane or dome leaves. The log -hives and woven hives (Tangal) are used in Kurdofan and Darfur (hanged among trees during Feb.- April) whereasKhartoum hive, Umdurman hive, Guffa hive, English hive and Kenyan hive were used in Kosti area in 1987[1].

Modern beekeeping: Modern beekeeping in Sudan was initiated at the faculty of Agriculture, University of Khartoum in 1961. Since that time, Langstroth hives, Cyprian, Italian, Carniolan queens and first hybrid Carnio -Egyptian colonies were imported. In 1979 National Beekeeping Project was established and small modern apiaries were then constructed to serve as extension models at different locations in central and eastern Sudan (Suki scheme). The major problem facing apiculturists in those apiaries is the regular inspection as a result of the aggressive behavior of Sudanese honey bees which makes the management of these bees very difficult and has hindered the development of the beekeeping industry in Sudan and other problem is the low of production of honey. To overcome these problems, some of the interested beekeepers introduced western honey bee races. Now most of the companies which working in the large scale of honey production, imported Carniolan package bees from Egypt. The Carniolan race has good traits, its extraordinary docility and calm, good honey producer, good comb builder, and adapted to some extend to Sudan condition. Sudan imported about (3970) kg Carniolan package bees from Egypt during the year 2014 [3].

Problem of the study: The contribution of banks in financing beekeeping industry is very weak and almost nonexisted. In spite of Sudan is very rich country in natural vegetation and rotational flowering times of different tree species, which represent the main food source of honey bees, the contribution of the honey and the other products such as (bee wax, pollen, royal jelly, propolis and venom) of gross domestic product (G. D. P) is insignificant.

Objectives of the study: The principle objective of this research is to design an integrated beekeeping project for submission to the Agricultural Bank of Sudan in order to be a guide for the bank to adopt and apply it as a tool of poverty reduction in rural areas of Sudan. And the other objectives are:

1. Estimate the increase of crops by using honey bees as pollinators.

2. Study the feasibility of beekeeping in the Sudan.

3. Study the marketing methods of honey inside and outside Sudan.

4. Study the amount of beekeeping investments through the Agricultural Bank of Sudan.

Hypotheses:

1. Crops pollinated by bees have been proven to produce higher yields and better quality

2. The beekeeping industry in Sudan is economically feasible.

3. Saudi Arabia is the main market for the Sudanese honey outside

4. The finance of this type of investment through the Agricultural Bank of Sudan is very weak

\section{Review of Literature}

Impact of beekeeping on preservation of forest and poverty alleviation in Sudan:

The area of Sudan is 188 million ha, about $12.6 \%$ is cultivated area (crops), $10 \%$ is covered by trees, $11.8 \%$ shrubs and $13.8 \%$ is covered by weeds. Sudan supplies over $80 \%$ of the world's needs of gum Arabic, extracted from the acacia. Production of round wood was estimated at 18.8 million (cu m) in 2000 , with $88 \%$ used as fuel (Forests National Corporation 2014 , in Arabic). Little is known about the importance of bees in nature preservation and agriculture, and the impact of beekeeping on the life of humans. In many ecosystems, bees are important pollinators ensuring the maintenance of those ecosystems. Beekeeping can also be a practical tool for raising the awareness of these communities of the importance of good 
management of their forests and for stimulating their conservation, thereby improving their biodiversity. It is important however, to realize that for beekeeping to become a sustainable activity, the necessary financial, extensional and technological support must be provided to fully exploit the great potential of beekeeping in the conservation of forest and natural ecosystems and in poverty reduction programmers [11]

Potential role of beekeeping in poverty alleviation:

Livelihoods strategies in rural areas in Sudan typically depend on agriculture and animal production in order to safe food security. Shocks such as floods, illness, political unrest or rising food prices can easily affect the household's ability to produce and purchase food. Beekeeping can be practiced as a safety net, providing households with extra income from the sales of honey and other beehive products, at the same time, bee products are nutritious food that can be an extra source of energy and nutrients. Honey can be easily stored, and sold or consumed in times of need. Beekeeping can be started up with few resources, even by landless households; bees collect nectar where they can. It is not a labour-intensive activity and can therefore easily be combined with the other daily activities. Beekeepers can organize themselves in beekeeping associations (The Sudanese Bee Keepers Union) to improve their techniques, increase production and strengthen their position on the local and abroad markets.

The returns from beekeeping will eventually contribute to the wellbeing of the whole community [7].

The importance of beekeeping in microfinance programmes:

In 2007 The Central Bank of Sudan (CBOS) has established a Microfinance Unit as an independent unit, both administratively and financially, within the sector of financial institutions and it has adopted preparation of a future vision and a strategy to develop microfinance sector as a tool to alleviate poverty in the country. So beekeeping industry is considered favorable tool in microfinance programmers because:

1. Beekeeping is a family activity which has a plenty of advantages compared to other types of agriculture.

2. It needs a relatively small investment. Low cost, low labour- intensive enterprise and does not require a lot of land and sophisticated inputs.

3. It is a flexible activity and viable for both sexes of any age, women, youth and other disadvantaged groups. Women can actively involve in beekeeping and processing of bee products: honey, beeswax (making candles and sewing the protective clothes, youth can involve in beekeeping, making beekeeping equipment and vending honey.

4. Beekeeping can be carried out as a productive secondary activity with low-level technology, or as a primary undertaking with more complicated techniques.

5. Beekeeping does not compete for resources with other types of agriculture - the nectar and pollen of plants are a true bonus.

6. All the apiary equipment is available in local market.
7. Marketing channels are available inside and outside country.

8. Beside production of honey and wax valuable products such as royal jelly, propolis, pollen grains and venom are produced.

9. Increase crops production beside intended crop (Honey).

10. It can be practiced in rural and remote areas and it can migrate from location to another according to the rotation of flowering.

11. Beekeeping generates income without destroying habitat [11].

National Initiations in Poverty Alleviation:

There are several attempts and initiatives conducted by the government through its various institutions in order to alleviate poverty such as:

The microfinance unit: The microfinance unit of the River Nile State (North of Sudan) in 2013, provides credit to the farmers through the ministry of the animal resources of the state. They provide every farmer 5 Langstroth hives ( 5 frames with brood. queen and bees) and equipment (complete protective clothes, smoker, feeder. tool, brush, and extractor sharing between 10 farmers). This project targeting low income farmers of the state (Shendi, Damer. Attbara and Abu hemed), and who have an area cultivated with fruits in addition to seasonal crops. The main objectives of this project are to reduce and alleviate poverty among farmers by increasing the production of crops through the bee pollination and improving nutritional status among people by consuming honey as food and providing households with extra income from the sales of honey and other beehive products.

Economic Importance of Beekeeping:

Beehive- products: Beehive products constitute nutrient food, healthy medicines (apitherapy) and raw material for industries (such as honey in food processing, or wax in batik making). Forests, being areas with no direct agricultural activity, offer a source of organic nectar. However, due to lack of knowledge of rural communities and bad practices, some valuable beehive products are often spoiled or simply disposed of without benefiting from their full potential, such as propolis, venom, royal jelly and pollen grains.

1. Honey: Honey is the most important primary product produced by the honeybees. It consists essentially of different sugars (95 to $99 \%$ of honey dry matter) predominantly glucose $(31.3 \%)$ and fructose (38.2\%) which represent $85-95 \%$ of total sugar, fructose is more abundant than glucose. honey contains a number of enzymes, amino acids, vitamins, minerals, antioxidants (flavonoids), amino acids and water 17.2\%. Honey is considered a valuable food and can improve the health and nutritional status of man, and also medicine for local resident. Moreover, honey is important cash crops offered on local markets, so ensuring economic growth and concrete input into economic development [18].

2. Bee wax: Beeswax is a natural secretion from wax glands on the four sternites of the young workers bees. It is used primarily as a building block for the bees' comb cells in which the young are reared and honey and pollen are stored and used 
to cap the ripened honey. It is also mixed with propolis and used for sealing cracks and covering foreign objects in the hive. To stimulate the production of beeswax, the honey bee feed themselves with honey and huddle together to raise the temperature of the cluster. To produce one pound of wax the bees consume about ten pounds of honey. The color ranges from yellow when newly secreted to almost black when being used for many years (old). Beeswax is extracted by boiling the honey comb. Beeswax today is widely used in pharmaceuticals, water proofing materials, polishes, candles. Furniture, cosmetics and has medicinal uses [4].

3. Royal jelly: Royal jelly, is a creamy white or pale yellowish substance secreted by the worker bees to feed the queen and the young larva inside the hive and is the queen bee's extraordinary source of food. It is a blend of secretions from the hypopharyngeal glands of the worker bee and contains a high concentration of vitamins B5, B6, and amino acids and is believed to be a potent antioxidant and a special rejuvenating substance that promotes tissue growth, muscle and cell regeneration. Royal jelly is rich in estradiol a major estrogen functioning as the primary female sex hormone. This natural substance is known to be effective in treating women who have problems with their menstruation such as abnormal cycle, pain, discomfort and fatigue.

4. Propolis: Propolis is a resinous material collected by bees from leaves and buds of certain trees. Its greenish -black in color and gummy in consistency. It's used by workers to line the inside of nest cavities and all brood combs. Repair combs, seal small cracks in the hive and dead animal or insects which are too large to be carried out. The major compounds of propolis are- Resins (45-55\%). Esters, Waxes and Fatty Acids (25-35\%), Essential oils (10\%), pollen (5\%). Other organics $(5 \%)$ and minerals $(1 \%)$. [12]. Because of antibacterial, antifungal, antiviral, anti-inflammatory and antioxidant effects Propolis has been shown to have outstanding value for a wide variety of illnesses. It is also used as ointments for healing cuts and wounds. Propolis can be purchased completely raw and unprocessed, but it in its natural state is a sticky substance and is very difficult to handle. Some beekeepers will package it raw and freeze it in small portions. It can then be added to a coffee grinder in its frozen stat and ground for easy consumption. (supplementpolice.com/propolis). Most producers utilize a process where the active ingredients are 'leached' into water or alcohol, then either packaged in liquid form or dried and capsulated. Because of its antibacterial, antifungal, antiviral, anti-inflammatory and antioxidant effects, this precious substance has been used as a natural cure and healing agent for many centuries. It has the ability to provide protection against infectious invaders, promote healing and regeneration of tissue, and provides a superior source of energy and stamina. Touted as an outstanding ointment for healing cuts and wounds and treatment for tonsillitis, mouth ulcers and intestinal infections [12].

5. Bee venom: Bee venom is a clear liquid with a sharp bitter taste, aromatic odour and acidic reaction. It's stored in the poison sac.
Toxicity: Bee stings cause human reactions in 2 distinct patterns. One or a few stings may induce allergic responses that are sometimes severe or fatal. On the other hand, massive attacks with hundreds to thousands of stings can cause severe systemic injury affecting many different organs, resulting in high mortality (at least 500 stings over a short period of time to cause death by direct toxicity). Melittin has been shown to be the main lethal component in bee venom. Bee venom contains several biochemically or pharmacologically active substances, including at least histamine, dopamine, melittin, apamin, mast cell degranulating peptides (MCDP), minimine, and enzymes. Venom can be collected without killing bees by electrical shock device. Bee venom is most effective when it comes directly from the live bees and it can be administered as solution, creams, liniments, and ointments [8].

6. Pollen grains: Pollen grains appear as tiny, white or golden specks, produced in thousands inside flowers. Each pollen grain is a microspore containing a male gametophyte, formed in the anthers of the higher flowering plants because plants are literally rooted to the spot where they grow, to achieve cross fertilization between plants, it is necessary for some part of the plant to be able to travel. This is achieved by the male pollen grains being dispersed to reach the female stigmas of other flowers. Insect-pollinated plants depend upon bees and other insects to transfer their pollen. Plants that need bees to transfer their pollen must provide incentive for the bees to do so, and nectar and pollen are the incentives that flowers use to encourage bees to visit them. Nectar and pollen are honeybees' only food sources: nectar is mainly a source of carbohydrate for honey production, while pollen provides all the other nutrients essential for honeybee development and growth. The anatomy of honeybees is well adapted for collecting pollen and packing it into the 'baskets' on the back legs of forager bees for carrying back to the hive. Once inter the hive, the forager may perform a dance to inform other bees how to locate her source of pollen [15]

Pollen as food for humans: Pollen has a highly valuable nutritional supplement for humans, because of the range of constituents and including the minor constituents which changes from species to species. Protein contents of about 40 percent, including all the essential amino acids, a full spectrum of vitamins and minerals, lipids, trace elements, hormone, enzymes, vitamins, carbohydrates and fatty acids, flavonoids and carotenoids, and many minor constituents, depending upon which plants the bees have been foraging [15].

Pollen is also harvested for use in plant breeding programmes, for pollination, for storage and subsequent feeding to bees in times of dearth, for use in the study of allergic responses such as hay fever, for Melissopalynology (pollen identification) as good tool to estimate the actual potentiality of beekeeping (honey consumers from Sudan appeared to prefer honey originated from Acacia spp and Ziziphus spp more than honey from other plants, and increasingly for monitoring for environmental pollution, most especially for the presence of heavy metals or residues.

Harvesting and Marketing pollen: After collection from a 
pollen trap, the best way to dry pollen is to use a pollen drier: this consist of trays on which the pollen is spread thinly, with a gentle airflow at $40^{\circ} \mathrm{C}$. This should be in the dark or lit with infrared. After drying, the pollen must be checked for any impurities that must be removed, and then stored cool and dry this method provides marketable pollen that is attractive, easy to store and sell. Pollen can be a useful crop to harvest and market. Commercialized harvesting of pollen tends to be especially successful in dry areas like Sudan, but in humid climates, special effort is needed to prevent pollen from becoming mouldy.

Pollination: Pollination is the transfer of pollen grains, the male sex cells of a flower, from the anther where they are produced to the receptive surface, or stigma, of the female organ of a flower, which occur either by wind, water or various animals mostly insects among which bees are the most important pollinators. Honey bees are good pollinators for many reasons. Their hairy bodies trap pollen and carry it between flowers. The bees require large quantities of nectar and pollen to rear their young, and they visit flowers regularly in large numbers to obtain these foods. In doing so, they concentrate on one species of plant at a time and serve as good pollinators for this reason. Their body size enables them to pollinate flowers of many different shapes and sizes. Honey bees has provided great economic value to the human, the maintenance of biodiversity and pollination of crops are the most valuable services provided by bees. The modern science has emphasized that about 80 percent of the crops, fruits and forest trees depend upon the bee pollination, and they found that the increase of the crop production was about $70-200 \%$ and in sometimes it may reach $400 \%$ which has happened in the citrus trees in Shambat University of Khartoum farm [1]. See the table 1, table 2, table 3 .

Table 1. Bees effect on the seeds production.

\begin{tabular}{llll}
\hline \multirow{3}{*}{ Pollinators } & \multicolumn{3}{l}{ The crops } \\
\cline { 2 - 4 } & Sun flower & Cotton & Alfa alfa \\
\cline { 2 - 4 } & Yield K/F & Yield K/F & Yield K/F \\
\hline Bees+insects & 652.3 & 867.2 & 121 \\
Bees & 566.1 & 769.4 & 109 \\
without pollinators & 72.5 & 585.8 & 33.3 \\
\hline
\end{tabular}

(Source: Abdella, 1991).

Table 2. Bees affectthe weight of the seeds.

\begin{tabular}{llll}
\hline & \multicolumn{3}{l}{ The crops } \\
\cline { 2 - 4 } Pollinators & Sun flower & Cotton & Alfa alfa \\
\cline { 2 - 4 } & Weight of & Weight of & Weight of \\
& $\mathbf{1 0 0 s e e d}(\mathbf{g})$ & $\mathbf{1 0 0 s e e d}(\mathbf{g})$ & $\mathbf{1 0 0 0 s e e d ~}(\mathbf{g})$ \\
\hline Bees + insects & 8.1 & 14 & 2 \\
Bees & 6.7 & 13.2 & 1.9 \\
without bees & 4.1 & 10.4 & 1.2 \\
\hline
\end{tabular}

(Source: Abdella, 1991).

Table 3. Bees effect on the oil percent of the seeds.

\begin{tabular}{lll}
\hline \multirow{3}{*}{ Pollinators } & \multicolumn{2}{l}{ The crops } \\
\cline { 2 - 3 } & Sun flower & Cotton \\
\cline { 2 - 3 } & Oil \% & Oil \% \\
\hline Bees + insects & $44 \%$ & $47 \%$ \\
\hline
\end{tabular}

\begin{tabular}{lll}
\hline Bees & $42.2 \%$ & $46 \%$ \\
without bees & $28 \%$ & $41 \%$ \\
\hline
\end{tabular}

(Source: Abdella, 1991).

Other study was conducted to assess the effect of honeybees in pollinating muskmelon in Silait north of Khartoum. The study showed that honeybees' pollination is highly effective on quantity of fruits per plant and the quality of the fruits such as, fruit size, number of seeds per fruit, seed germination percentage, the shape and netting [10].

Therefore, honeybees' pollination is highly effective on quantitative and qualitative of the crops in the Sudan. (This confirms the validity of the first hypothesis).

Marketing of honey bee in Sudan.

Marketing is the social process by which individuals and groups obtain what they need and want through creating and exchanging products and value with others.

Channel of distribution:

The manner in which to place a product into the hands of the customer. The purpose of the channel of distribution is to bridge the gap between the producer of product and the user of it. Marketing channel is a set of practices or activities necessary to transfer the ownership of goods, from the point of production to the point of consumption. It is the way products and services get to the end-user. A marketing channel is a useful tool for management, and is crucial to creating an effective and well-planned marketing strategy [11]

Types of Marketing Channels:

There are four main types of marketing channels:

\subsection{Producer to Customer}

The producer sells the goods or provides the service directly to the consumer with no involvement with a middle man such as an intermediary. The consumer goes directly to the producer to buy the product without going through any other channel. This type of marketing is most beneficial to farmers who can set the prices of their products.

\subsection{Producer to Retailer to Consumer}

Retailers buy the product from the manufacture and sell them directly to the consumer. This channel it is in the best interest of the manufacturer to sell them to another user before it gets into the hand of the consumers.

\subsection{Producer to Wholesaler/Distributor to Customer}

Wholesalers buy the products from the manufacture and sell them to the consumer. In this channel, consumers can buy products directly from the wholesaler in bulk. However, the wholesaler does not always sell directly to the consumer. Sometimes the wholesaler will go through a retailer before the product gets into the hands of the consumer. This raises the price of the product for the end-user.

\subsection{Producer to Agent/Broker to Wholesaler or Retailer to Customer}

This distribution channel involves more than one 
intermediary before the product gets into the hands of the consumer. This middleman, known as the agent, assists with the negotiation between the manufacturer and the seller. Agents come into play when the producers need to get their product into the market as quickly as possible. This happens mostly when the item is perishable and has to get to the market fresh before it starts to rot. At times the agent will directly go to the retailer with the goods, or take an alternate route through the wholesaler who will go to a retailer and then finally to the consumer.

Electronic marketing: The use of internet and related digital information and communication technologies to achieve marketing objective. Electronic marketing is a new concept of marketing and it can benefit the beekeeping industry in Sudan by creating new markets and new buyers over the world and facilitate the shipment and payment process.

\section{Research Methodology}

Data Collection:

This study was conducted in some regions in River Nile State, North Kordufan State, White Nile State. The study was based mainly on primary data collected through field survey, questionnaire and interviews. This questionnaire was prepared in order to obtain information on quantities, costs of inputs related to honey production and social characteristic of beekeepers. Interview process with the manager of the Agricultural Bank of Sudan Micro-finance Initiative (ABSUMI). The primary data were supported by secondary data from the ministry of the Social Affairs. Zakat Chamber, Agricultural quarantine (Khartoum Airport) and the Agricultural Bank of Sudan.

Data Analysis:

The process of evaluating data using analytical and logical reasoning to examine each component of data provided. The data collected was subjected to descriptive analysis and based on tabular and budget analysis. Cost was analyzed by the percentage of any item from the total cost to show the share of any item cost and to determine the total cost items.

The average cost items $(\mathrm{Qa})=\frac{\sum \mathrm{Qi}}{\mathrm{N}}($ Eltoum, 1999)

The percentage of individual cost item $=\frac{\mathrm{Qa}}{\mathrm{Q}} \times 100$ (Eltoum, 1999)

Where:

$\mathrm{Qa}=$ The average cost items.

$\mathrm{N}=$ The sample size

$\mathrm{Q} \mathrm{i}=$ The individual cost item.

$\mathrm{Q}=$ The average total cost..

Budget analysis was used to determine total costs and total returns based on the average prices, average yield and the total average variable costs. The enterprise gross returns are obtained by multiplying the average price by the average yield the enterprise gross margin is equal enterprise gross output minus enterprise variable costs [17].

\section{Results and Discussions}

This research was conducted to study the importance of beekeeping in pollination, the economic feasibility, the marketing of the honey bees and the role of the Agricultural Bank of Sudan in financing beekeeping.

Effect of bee pollination on the yield of the different cultivated crops:

The field survey in the River Nile state duringthe year 2015 showed that the production has increased and reached $423 \%$ in onion seeds, table 4 , which confirms the validity of the first hypothesis, the farmers beside their benefits in pollinating crops and high fruits production they gain cash from purchasing honey in the local markets.

Table 4. Effect of bee pollination on the yield of the different cultivated crops.

\begin{tabular}{lllll}
\hline \multirow{2}{*}{ Crop } & \multicolumn{2}{l}{ Av of production/Kg/f } & \multirow{2}{*}{$\begin{array}{l}\text { No. of } \\
\text { hives }\end{array}$} & \multirow{2}{*}{ Increase } \\
\cline { 2 - 3 } & Before & After & 4 & $49.9 \%$ \\
\hline Orange & 6875 & 10312 & 4 & $43.7 \%$ \\
Faba bean & 1000 & 1437.5 & 4 & $423 \%$ \\
Onion seeds & 55.5 & 288.5 & 2 & $60 \%$ \\
Coriander & 1750 & 2800 & 2 & \\
\hline
\end{tabular}

(Source: Survey 2015).

Budget for honey production:

The net return is equal the gross return minus (variable cost plus depreciation). The Return on investment is calculated by the net return is divided by the total costs. Table 5 shows that the extractor and the bees represent high percentage (35.6\%), $(24.2 \%)$ of the total costs. However, the extractor can be shared between two beekeepers or more.

Table 5. The average of fixed cost.

\begin{tabular}{lll}
\hline cost item & Average cost/colony & \% \\
\hline Nucleus hive & 800 & 24.2 \\
Building & 550 & 16.6 \\
Wax foundation & 80 & 2.4 \\
Feeder & 44 & 1.3 \\
Smoker & 105 & 3.2 \\
Hive tool & 65 & 2 \\
Bee brush & 65 & 2 \\
Un capping fork & 55 & 1.7 \\
Extractor & 1175 & 35.6 \\
Protective clothes & 360 & 11 \\
Total & 3299 & \\
\hline
\end{tabular}

(Source: Survey 2015).

Table 6. Analysis of total average variable costs.

\begin{tabular}{lll}
\hline Item & Average & $\mathbf{\%}$ \\
\hline Labour & 34.6 & 27.6 \\
Maintanence & 14.4 & 11.5 \\
Artificial feeding & 26.3 & 21 \\
Water & 5.2 & 4.1 \\
Mobilization vessels & 14.4 & 11.5 \\
Bottels & 25 & 19.9 \\
Other & 5.3 & 4.2 \\
Total & 125.2 & \\
\hline
\end{tabular}

(Source: Survey 2015).

Through the data which collected from different modern 
apiaries of River Nile, White Nile and North Kordufan States and the budget analysis, table 7 it is clear that the beekeeping industry is economically feasible, $(46 \%$ Return on investment, the gross return per hive is very high, 1583.1) pound.

Table 7. Budget for honey production.

\begin{tabular}{ll}
\hline Cost items & Pound/Colony \\
\hline Labour & 34.6 \\
Maintenance & 14.4 \\
Artificial Feeding & 26.3 \\
Water & 5.2 \\
Mobilization Vessel & 14.4 \\
Bottles and labels & 25 \\
Other & 5.3 \\
Total Variable Cost & 125.2 \\
Total Fixed Cost & 3299 \\
Yield per Colony (kg) & $19.3(\mathrm{Kg})$ \\
Prices / $\mathrm{k}$ & 95 \\
Gross Return & 1833.5 \\
Gross Margin & 1583.1 \\
\hline
\end{tabular}

(Source: Survey 2015).

\section{The Gross Returns $=19.3 \times 95=1833.5$}

The gross margin $=1833.5-(250.4)=1583.1$ (two seasons)

The return on investment $=\frac{1583.1}{3549.4} \times 100 \%=44.6 \%$

Social characteristics of beekeepers:

The social characteristics of beekeepers such as sex, age, job, education level and trainings has a great effects on the apiaries management and hence the production.

1. Sex: table 8 shows that $100 \%$ of beekeepers are men, because beekeeping as activity is associated and integrated with farming or grazing which practiced by men.

Table 8. Distribution of beekeepers by sex.

\begin{tabular}{lll}
\hline Item & Number of beekeeper & $\mathbf{\%}$ \\
\hline Men & 30 & 100 \\
Women & 0 & 0 \\
Total & 30 & 100 \\
\hline
\end{tabular}

(Source: Survey 2015).

2. The job: Beekeeping in Sudan is practiced as supportive job, not the main job. Table 9 shows that $93.3 \%$ of beekeepers have another work; this can reduce the management performance.

Table 9. Distribution of beekeepers by their jobs.

\begin{tabular}{lll}
\hline Item & Number of beekeeper & $\mathbf{\%}$ \\
\hline Main job & 2 & 6.7 \\
Have another job & 28 & 93.3 \\
Total & 30 & 100 \\
\hline
\end{tabular}

(Source: Survey 2015).

3. Beekeeping methods: Table 10 shows that about $96.7 \%$ of modern apiaries were fixed and produce honey in one or two seasons only, whereas migratory beekeeping represent $3.3 \%$ and produce honey from more than two seasons and benefit for pollination.

Table 10. Distribution of beekeepers by methods of beekeeping.

\begin{tabular}{lll}
\hline Item & Number of beekeeper & $\mathbf{\%}$ \\
\hline Fixed beekeeping & 29 & 96.7 \\
Migratory beekeeping & 1 & 3.3 \\
Total & 30 & 100 \\
\hline
\end{tabular}

(Source: Survey 2015).

3. The age: Age is assumed to have a positive effect on productivity until a certain level beyond which it would start to decrease [9] Age of the beekeepers is presented in table 11, shows that about $53.3 \%$ of beekeepers are between 30 and 40 years, and $33.3 \%$ of the beekeepers are between 41 and 50 years, this range of age is consider a productive age.

Table 11. Distribution of beekeepers by age.

\begin{tabular}{lll}
\hline Item & Number of beekeeper & $\mathbf{\%}$ \\
\hline $30-40$ Years & 16 & 53.3 \\
41-50 Years & 10 & 33.3 \\
Over 51 Years & 4 & 13.4 \\
Total & 30 & 100 \\
\hline
\end{tabular}

(Source: Survey 2015).

4. Educational level: Table 12 shows that about $60 \%$ of beekeepers had secondary education, implying that they could easily comprehend and use new techniques in their beekeeping enterprise.

Table 12. Distribution of beekeepers by educational level.

\begin{tabular}{lll}
\hline Item & Number of beekeeper & $\mathbf{\%}$ \\
\hline Post graduate & 2 & 6.6 \\
Graduate & 6 & 20 \\
Secondary & 18 & 60 \\
Primary & 4 & 13.4 \\
Total & 30 & 100 \\
\hline
\end{tabular}

(Source: Survey 2015).

5. Honey bee race: Table 13 shows that about $66.7 \%$ of beekeepers are prefer to use carniolan bees than natives, because foreign bees are gentle and calm so it is easy to deal with.

Table 13. Distribution of beekeepers by the races of bees.

\begin{tabular}{lll}
\hline Item & Number of beekeeper & \% \\
\hline Carniolan races & 20 & 66.7 \\
Sudanese races & 6 & 20 \\
Mixed races & 4 & 13.3 \\
Total & 30 & 100 \\
\hline
\end{tabular}

(Source: Survey 2015).

6. Source of credit: Table 14 showed that $73.3 \%$ of beekeepers were financed through the microfinance units, and only $6.7 \%$ through the government. Notably, the total absence of the role of the banks in this type of investment. 
Table 14. Distribution of beekeepers by type of the source of credit.

\begin{tabular}{lll}
\hline Item & Number of beekeeper & $\mathbf{\%}$ \\
\hline Governmental finance & 2 & 6.7 \\
Micro finance - Unit & 22 & 73.3 \\
Private & 6 & 20 \\
Total & 30 & 100 \\
\hline
\end{tabular}

(Source: Survey 2015).

7. Training: All beekeepers had a basic training, that implies they could manage their apiaries properly, good management is considered the backbone of the success of any project table 15 .

Table 15. Distribution of beekeepers by training courses.

\begin{tabular}{lll}
\hline Item & Number of beekeeper & $\mathbf{\%}$ \\
\hline One training course & 20 & 66.7 \\
Two training course & 10 & 33.3 \\
Total & 30 & 100 \\
\hline
\end{tabular}

(Source: Survey 2015).

Local and abroad marketing of Sudanese honey:

Local marketing:

The major product of beekeeping sold to local markets are honey and bee wax. Honey producers largely sell their honey in the nearest local markets carrying their products by themselves or by their donkeys when they have large productions, this type of honey is collected from nearby traditional hives. Table 16 shows $53.3 \%$ of the beekeepers are depending on retailers to purchase their honey whereas only $10 \%$ of them are depending on the wholesalers.

Table 16. Methods of Sudanese honey marketing

\begin{tabular}{lll}
\hline Marketing Methods Marketing methods & Beekeepers & \% \\
\hline Producer to Customer & 11 & 36.7 \\
Producer to Retailer to Consumer & 16 & 53.3 \\
Producer to Wholesaler/Distributor to Customer & 3 & 10 \\
Total & 30 & 100 \\
\hline
\end{tabular}

(Source: Survey 2015).
Constrains affecting negatively on the quality of the honey and consequently the price of the honey. Which are:

1. The honey is mixed with impurities as a result of lack of straining materials, lack of knowledge of straining or they thought that the amount of honey will be reduced when strained.

2. Producers grade their honey for sale based on personal evaluation and no standard for quality.

3. Packaging, beekeepers sell their honey in whatever containers are available such as drink bottles which are not attractive for the consumers. Honey containers must be perfectly clean and must never be sticky with honey.

Khartoum the capital of Sudan is considered the central market of the honey and the price is very high compared with other markets in Sudan (120-170) pounds, table 17.

Table 17. The main markets of honey in the Sudan.

\begin{tabular}{ll}
\hline The market & Average (price/pound/kg) \\
\hline Khartoum & $120-170$ \\
Umrawaba & 100 \\
Nyala & 105 \\
Fashir & 100 \\
Fropranga & 100 \\
Zalingi & $90-100$ \\
Taludi & $90-100$ \\
Rashad & $90-100$ \\
Abuggibaiha & 90 \\
\hline
\end{tabular}

(Source: Survey 2015).

Abroad marketing:

The growing demand for organic honey has opened opportunities for honey producers in the Sudan to inter the markets over the world specially the Arab countries. Saudi Arabia is considered the main market of the Sudanese honey, table 18. (This confirms the validity of the third hypothesis).

Table 18. Exported honey during 2012, 2013, 2014 to some countries.

\begin{tabular}{lllll}
\hline Country & $\mathbf{2 0 1 2}$ (Mass)/Kg & $\mathbf{2 0 1 3}$ (Mass)/Kg & 2014 (Mass)/Kg \\
\hline Saudi Arabia & 2412 & 1870 & 2230 & 0 \\
Suriname & 0 & 1200 & 183 & 6512 \\
Arab Emirates & 200 & 200 & 91 & 583 \\
Germany & 25 & 0 & 0 & 1200 \\
Egypt & 0 & 150 & 125 & 150 \\
Qatar & 0 & 0 & 2629 & 125 \\
Total & 2637 & 3420 & 8686 \\
\hline
\end{tabular}

(Sources: Sudan Custom 2015).

Agricultural bank of Sudan is widespread bank and has more than hundred branch covered all the agricultural areas of Sudan, so it is qualified to bea leader in poverty reduction and rural development targeting different activities such as poultry, milk and meat production, fishery, gum production and beekeeping. However, the beekeeping activity has been ignored and represents very low percentage $(0.07) \%$ of the total finance of the animal production during2014 table 19 for many reasons:
1. No updated policy of beekeeping finance.

2. Lack of information about to what extend beekeeping is economically feasible.

3. No specialist employee in beekeeping in order to study and analyze the feasibility studies which submitted by the applicants and write a technical report about the project.

The table 19 showed the very low beekeeping credit percentage (0.07) \% of the total credit of animal production which granted by the agricultural bank of Sudan, (This which 
confirms the validity of the fourth hypothesis).

Table 19. Percentage of beekeeping finance compared with other activities.

\begin{tabular}{lll}
\hline Items & Total of finance & \% \\
\hline Milk production & $95,322,629$ & 37.7 \\
Meat production & $74,644,065$ & 29.5 \\
Poultry & $36,116,883$ & 14.3 \\
Fish production & $1,160,358$ & 0.43 \\
Beekeeping & 182,400 & 0.07 \\
Others & $45,587,164$ & 18 \\
Total & $253,013,499$ & 100 \\
\hline
\end{tabular}

(Source: Annual Report [2]).

\section{Conclusions}

This research has described the many roles that bees can play in nature preservation, agriculture and the positive impact that beekeeping can have on the lives of humans. Recognizing the contribution of bees to the livelihoods of communities, and the role of beekeeping as a tool in poverty reduction by designing an integrated project to the banks and other financial institution for inclusion in future polices. Beekeeping industry in the Sudan is widespread in cultivated areas and practiced by individuals in small scale and companies in large scale as a modern system, however the traditional system is still practiced in Kordufan, Darfur and Blue Nile States.

The honey produced by traditional system is marketed locally whereas the honey produced by modern system is marketed abroad to the Gulf and Arab countries. This study was conducted in the states that have a modern apiaries in the Sudan. (River Nile State, North Kordufan State and White Nile State). The main objective of this study is to design a project for beekeeping in Sudan consistent with the Agricultural bank of Sudan policy as medium - term loan, for the purpose of introducing it within the bank financing map in rural development and poverty alleviation. Primary data were collected by field survey to thirty modern apiaries in north Kordufan state, river Nile state and white Nile state, and interview with the manager of the Agricultural Bank of Sudan Micro-finance Initiative (ABSUMI). secondary data collected from ministry of agriculture, Sudan custom, agricultural bank of Sudan, Zakat chamber, Agricultural quarantine (Khartoum airport) and the ministry of social affairs. Based on the findings of this study, the contribution of the agricultural bank of Sudan in financing beekeeping is very weak and almost non- existed about $(0.07 \%)$ of the total of animal production finance. The analysis of social and economic characteristics of the beekeepers revealed that all of beekeepers are men, educated and they have basic training in beekeeping. All beekeepers are within the productive age (30-60 years). Beekeeping is additional job and not the main job for $(93.3 \%)$ of the beekeepers and (96.7\%) of the beekeeper are practiced fixed beekeeping using carniolan bees by $67 \%$ of them. The analysis of the budget and the cost revealed that the bees (nucleus bees) was the main cost item for honey production, as it constituted about $24.2 \%$ of the total cost. The honey is the main product and the average yield was about $19 \mathrm{Kg} /$ colony, the return was greater than the cost and the return on investment was $36.6 \%$.

\section{Recommendations}

Based on the finding of this study, the following recommendations are given:

1. To create associations of local producers to develop productions and marketing process locally and abroad.

2. To encourage the banks and other financial institutes to engage in this type of investment.

3. To encourage the export process by simplifying procedures.

4. To train beekeepers to improve their skills and knowledge regarding honey production.

5. To encourage scientific research on beekeeping industry.

6. To establish a queen rearing unit to meet the local demands of package bees.

\section{References}

[1] Abdella, M. A. (1991). Beekeeping in Sudan - University of Khartoum House for Publishing, Pages 88-89, 159.

[2] Agricultural Bank of Sudan, (2014). Annual report for year 2014. Khartoum, Sudan.

[3] Agricultural Quarantine, Khartoum Airport, (2015).

[4] Birshtein, V. Y; Tulchinskil, V. M; Troitiskil, A. V. (1976). A study of organic components in ancient Central Asian and Crimean wall paintings. Vestnik Moskosvkogo Universiteta 31 (3): 33-38.

[5] Central Bureau of Statistics, Khartoum, Sudan (2010): National Baseline Household

[6] Survey (NBHS, 2007, 2009, 2010).

[7] Charlotte Lietaer XIII (2009). World Forestry Congress. Buenos Aires,. Impact of beekeeping on forest conservation, preservation of forest ecosystems and poverty reduction.

[8] Dotimas, E. M. and Hider, R. C. (1987). Honey Bee Venom. Bee world, 68 (2); 59-64.

[9] Eltoum. Y. A. A. (1999). Economics of beekeeping industry in Sudan, M. Sc thesis, university of Khartoum.

[10] Elmatry. R. M. U. (2013). The role of honey bee pollination on qualitative and quantitative parameters of musk melon export, M. Sc thesis, Sudan Academy of Sciences.

[11] F A O, 124 Value - added products beekeeping. (2007) web site, www.fao 2007.com.

[12] Greenaway, W, May, J. Scaysbrook, T. and Whatley F. R. (1990) Identification by gas chromatography-mass spectrometry of 150 compounds in propolis.

[13] National Forestry Commission, (2014).

[14] Rashad, S. and EL- Sarrag, M. S. A. (1978). Beekeeping in Sudan. Bee World.59 (3); 105-111. 
[15] Schmidt and Buchmann, (1992). The Hive and the Honey Bee, Hamilton, Illinois.

[16] Sudanese Customs, (2015).
[17] Upton, M. (1976). African Farm Management. Cambridge University Press, 126.

[18] White, J. W; Riethof, A. Land. Kushnir, I (1962). Composition of American honeys 38-39. 